\title{
Determinants of Expenditure Patterns of Unconditional Cash Transfer Receipts in Kenya
}

\author{
Benson A. Ateng', Senior Lecturer (Corresponding author) \\ P.O. Box 79803 - 00200, Nairobi, Kenya \\ E-mail: bensonateng@gmail.com \\ Judith A. Odhiambo, Tutorial Fellow \\ Department of Economics and Resource Management, \\ The Technical University of Kenya
}

\begin{abstract}
Cash transfers take different forms -- unconditional or conditional. Higher- and middle-income Kenyans support the poor through cash and in-kind transfers. These private/individual transfers supplement the Government's own cash and in-kind transfer programmes. Non-profit institutions and corporate sector are also involved in cash and in-kind transfers. However, some policy makers and others are skeptical about the viability of unconditional cash transfer programmes. They fear that poor households will use such cash transfers to buy alcohol, tobacco, or other "temptation goods."This paper aims at: establishing the determinants of the items on which unconditional cash transfers are spent at the household level; determining if the concern often expressed by policy makers and others that poor households will use cash transfers to buy the so called "temptation goods" is justified; and determining if a case can be made for unconditional cash transfer in Kenya. We employed a multivariate regression technique to establish the determinants of cash transfer expenditures, using nationally representative household survey data. Our findings show that unconditional cash transfers are spent on food, education/school fees, health, investment/business, rent/housing, clothing, debt repayment, and others. Overall, households in Kenya seem to make "sensible" decisions in their expenditure of such income. They spend the money on items that are in line with their socioeconomic situation. The highest proportion of such income is spent on education which they consider as investment in human capital of their children. Next is expenditure on food and the pattern is consistent with our prior expectations. Expenditures on the so called "temptation goods" seem to be very small, if at all. These key priority expenditure patterns seem to invalidate the concern that cash transfers may be just "handouts" that promote purchase of the so-called "temptation goods" in addition to leading to dependency. Factors that influence how the recipients spend the cash include the household's poverty severity rating, food poverty rating, location (urban or rural), nutritional status and gender and education level of head of household.In light of the above findings, when planning and executing government's social protection programmes, the recipients should be given greater say than has been the case hitherto. During the disruptive times, there are opportunities for innovation in policy formulation and management of cash transfer programmes, especially the unconditional ones. The Government, donors, corporate and NGO sectors should be open to such innovations and the beneficiaries should be given lee-way in deciding how to spend the money, especially in disruptive times. This would improve effectiveness and sustainability of such programmes.
\end{abstract}

Keywords: Cash transfer, multivariate regression, E-Views, pooled panel data

DOI: $10.7176 / \mathrm{JESD} / 13-4-05$

Publication date: February $28^{\text {th }} 2022$

\section{Introduction}

\subsection{Background}

We were motivated to undertake this study by a number of observations. Higher- and middle-income Kenyans support the poor through cash and in-kind transfers. These private individual transfers supplement the Government's own cash and in-kind transfer programmes. Non-profit institutions and corporate sector are also involved in cash and in-kind transfers. The transfers are either in form of cash or in kind and households can either receive or give out to other entities. The transfers comprise: (i) cash; (ii) food; (iii) clothing; (iv) healthcare/medical services; and (v) other in-kind support/gifts.

For the purposes of this research, we focused on cash transfers and adopted the official definition in Kenya where transfers are defined as "the provision of support or gift either in form of a good, service, financial asset or other assets by an individual, household or institution to another entity without any corresponding economic return." ${ }^{1}$ Thus, transfers comprise income that the household receives without working for it and supplements household income by improving its welfare.

Cash transfers take different forms -- they can be unconditional or conditional. An unconditional cash transfer

${ }^{1}$ Kenya National Bureau of Statistics, Basic Report 2015/16 Kenya Integrated Household Budget Survey, March 2018, p. 132. 
to beneficiaries does not involve any restriction on use -- beneficiaries are free to decide how they wish to spend it. These transfers can be universal or restricted (or targeted) to a specific sub-population, for example, the poor, elderly, and nursing mothers. Conditional cash transfer schemes essentially transfer cash, generally to target households, contingent on specific behavioural responses on the part of the household. These conditions can require that households make pre-specified investments in the human capital of their children, be employed in public works, use specific healthcare facilities, and so on ${ }^{1}$. In Kenya, some of the cash transfer programmes (such as elderly cash programmes) are unconditional. Some corporate cash transfer programmes (such as school fees programmes) are conditional -- that is, targeted to needy students. Transfers from individuals and friends are generally not targeted.

A number of studies have been carried out on cash transfer programmes in Kenya. For example, Innovations for poverty action (Ipa) conducted a randomized assessment to establish the impact of unconditional cash transfer, "GiveDirectly," between 2011 and 2014. The findings indicated that the programme improved the welfare of the locals. In addition, it was established that unconditional transfers are cheaper to administer than conditional transfers because they do not need any monitoring. However, we did not come across any study on the determinants of the items on which the unconditional cash transfers are spent.

We were also keen to find out if it was time for the Kenya Government to rethink the mechanisms of implementing its policy towards supporting food insecure groups. From time to time the Government is involved in food relief programmes, especially in the arid and semi-arid areas of the country. Food security is one of the Government's 'big four' development priorities. However, delivering food to the vulnerable groups requires a lot of logistical planning and, sometimes, relief food does not reach the recipients in a timely manner. Food relief in the form of unconditional cash transfer to the needy may be a better alternative. With the rapid advancement in electronic money transfer in the country, food aid (in the form of cash) would reach the recipients almost instantaneously. The only worry, frequently stated by policymakers and others, is that poor households will use unconditional cash transfers to buy the so-called "temptation goods" such as alcohol, tobacco, and so on. It would be useful to establish if such worries are justified in the context of Kenya.

We were also motivated by the finding from literature review that cash transfers, which put cash directly in the hands of the people for whom aid is intended, make up a very small proportion of aid and charitable giving. The poor rarely get to decide how aid money intended to help them gets spent. This study sought to find out the factors that influence how the beneficiaries spend unconditional cash transfers and if such cash transfers are spent responsibly.

\subsection{Objectives of the Study}

This paper aims at: (i) establishing the determinants of the items on which unconditional cash transfers are spent at the household level; (ii) determining if the concern often expressed by policy makers and others that poor households will use cash transfers to buy the so called "temptation goods" is justified; and (iii) determining if a case can be made for unconditional cash transfer in Kenya.

\subsection{Research Questions}

We set out to answer the following research questions to enable us achieve the objectives of the study:

1. Does poverty level influence how the recipients spend cash transfers? Do households with high overall estimates of poverty severity levels spend more on food than the ones with lower poverty severity rates?

2. Do households with higher food poverty headcount rates spend higher proportions of the cash transfer receipts on food than their counterparts with lower rates? Is there correlation between food poverty headcount rates and proportion of cash transfer receipts spent on food?

3. Do households with higher proportions of undernourished children spend higher proportions of the cash transfers on food and health services than their counterparts with lower proportions of malnourished children?

4. Does the sex of the head of household affect how cash transfers are spent?

5. Does the level of education of the head of household influence the pattern of expenditure of cash transfer receipts?

6. Does the location (rural or urban) of the household have any influence on how cash transfer receipts are spent?

7. Do households make "sensible" decisions in their expenditure of unconditional cash transfer receipts?

\footnotetext{
${ }^{1}$ Baird, S, Ferreira, F H G, Özler, B. and Woolcock, M. (2014). "Conditional, Unconditional and Everything in between: A Systematic Review of the Effects of Cash Transfer Programmes on Schooling Outcomes", Journal of Development Effectiveness 6 (1). doi:10.1080/19439342.2014.890362.

${ }^{2}$ Programme on poor households in Rarieda Constituency (Siaya County). Featured in "The Economist”: Impact of unconditional cash transfers on general welfare in Kenya, by Haushofer and colleagues.
} 


\section{Methodology}

There are many plausible factors that may influence the way in which unconditional cash transfers are spent by households in Kenya. We applied a multivariate linear regression model ${ }^{1}$ to help us determine those factors.

\subsection{Generating List of Potential Dependent and Independent Variables}

Dependent variables: Our dependent variables are the items on which the cash transfers are spent. They include cash transfer expenditure on food, education/school fees, health, investment/business, debt repayment, rent, and other. We also considered cash transfer rate itself as a dependent variable.

Independent variables: The expenditure items may be influenced by a wide range of factors that may include severity of poverty, food poverty (headcount rate), morbidity status, nutritional status (underweight), sex of head of household, level of education of head of household, and location of household (rural or urban).

We outline below plausible reasons for our selection of independent variables:

1. Poverty severity rate: Holding other things constant, one would expect to see a positive correlation between poverty headcount rates and proportion of cash transfer receipts spent on food. Thus households with higher overall estimates of poverty severity levels would be expected to spend more of the cash transfer receipts on food than the ones with lower poverty severity rates.

2. Food poverty rate: Similarly, one would expect to see a positive correlation between food poverty headcount rates and proportion of cash transfer receipts spent on food. Consequently, households with higher food poverty headcount rates would be expected to spend higher proportions of the cash transfer receipts on food than their counterparts with lower rates.

3. Nutrition level: We used "underweight" (low weight for age) in this study as a measure of nutritional status. It is a composite index of weight for height and height for age. The proportion of underweight children reflects both conditions of chronic and acute under-nutrition and is a pointer to the extent of nutritional problems. So we would expect households with higher proportions of undernourished children to spend higher proportions of the cash transfers on food and health services.

4. Education level of household head: Level of education of head of household (no education, primary, secondary, post-secondary) would be expected to influence the way the cash transfer receipts are spent.

5. Sex of head of household: We were curious to find out if and how sex of household head may influence how cash transfer receipts are spent.

6. Location: The location of the household (rural or urban) may also have some influence on how the cash transfers are spent. For example, households living in urban areas are more likely to spend the cash transfer receipts on rent than their counterparts in the rural areas who are more likely to live in their own houses.

\subsection{Model Specification}

Based on the above discussion, this study adopts an argument that the pattern of cash transfer expenditures is a function of: Poverty Severity Rate (PSR); Food Poverty Rate (FPR, head count); Nutrition Level (NUT); Male Household Head (MALE); Female Household Head (FEMALE); No Education for Household Head (NONE); Primary Education for Household Head (PRIMO); Secondary Education for Household Head (SECO); PostSecondary Education for Household Head (POSEC); Household in the Rural Area (RURAL) and Household Located in the Urban Area (URBAN).

Using Cross section pool objects estimation, we applied a simple model of the form:

$\gamma_{i, t}=\propto+X_{i, t} \beta_{i, t}+\delta_{i}+\gamma_{t}+\varepsilon_{i, t}$

where: $\gamma_{i, t}$ is the dependent variable

$X_{i, t}$ is a vector of regressors

$\beta_{i, t}$ are the coefficients of the independent variables (regressors)

$\varepsilon_{i, t}$ are the error terms observed for the cross-section units

$\propto$ represents the overall constant in the model

$\delta_{i}$ and $\gamma_{t}$ represent cross-section or period specific effects

E-Views pool object was used since it allows model estimation using least squares, with correction for fixed or random effects in the cross-section and period dimensions -- Auto Regressive (AR) errors, Generalized Least Squares (GLS) weighting, and robust standard errors, all without rearranging or reordering the data.

To estimate this model, we used data on Cash Transfer Rate (CTR) as Y and the 11 independent variables as the Xs for Kenya's 47 Counties as cross sections. The dataset was organized in excel to consist of the 11 variables with 47 Counties observed in 2005/06 and 2015/16 (2006 and 2016 as the cross section identifiers). In order to estimate the cross section pool model using this data, the data was stacked to have data on the 11 variables for each County. The data was then exported to E- views 10 work file for analysis.

\footnotetext{
${ }^{1}$ Pertaining to multiple dependent variables and multiple independent variables
} 
The Pooled Least Square method was used for analysis. In computing the output, the White heteroscedasticity cross section method treats the pool regression as a multivariate regression with an equation for each cross section. It then computes robust standard errors for the system of equations, accommodating arbitrary heteroscedasticity and within cross-section serial correlation. Thus allows for a different residual variance for each cross section. Residuals between different cross sections are assumed to be zero. Autoregressive (AR) models are used as a way of explicitly accounting for autocorrelation in the error allowing for valid inference.

\subsection{Data source}

We used, for our analysis, nationally representative household survey data sourced mainly from Kenya National Bureau of Statistics publications (2007 and 2018). We acknowledge that the period 2005/2006 was before the County units came into existence and data was reported according to Districts. For this purpose, we aggregated the respective districts that formed the County units as a basis for analysis within the 47 Counties.

\subsection{Diagnostic checks}

Given that panel data combines time series and cross-sectional data, it was important to perform the following diagnostic tests: heteroscedasticity, autocorrelation, multicollinearity and cointegration (help determine stationarity). Given the presence of cross-section component to panel data, there is always potential for heteroscedasticity. Cointegration tests are done when time-series are suspected to have non-stationary trends, to determine if they have a stable long-run relationship. The presence of unit roots in time-series depict unpredictable patterns, hence the need for unit-root testing. We used Augmented Dickey-Fuller (ADF) ${ }^{1}$ and Phillips Pheron (PP) ${ }^{2}$ unit-root tests. Serial correlation is usually a problem when dealing with macro panels. ${ }^{3}$ Ours is micro panel data $^{4}$. There is a general assumption that disturbances in panel data models are cross-sectionally independent. ${ }^{5}$ Besides, cross-section dependence tends to be more of a problem in macro panels (where there are long timeseries).

The Breusch-Pagan (B-P)/Lagrange Multiplier (L-M) was used to test for autocorrelation. It is commonly assumed that disturbances in panel data models are cross-sectionally independent, especially when the crosssection dimension is large. There is, however, considerable evidence that cross-sectional dependence is often present in panel regression settings. The Breusch-Pagan Lagrange Multiplier test is appropriate with fewer number of cross-section series settings. Pesaran CD gives an alternative statistic based on average of the pairwise correlation coefficients. Based on the statistic and p-values, we fail to reject the null hypothesis of no autocorrelation at conventional significance levels. The null hypothesis for this test is that there is no cross-section dependence (correlation). It included a total of 88 panel observations for 2005/06 and 2015/16. Non-zero crosssection means detected in the data and cross-section means were removed during computation of correlations.

Table 1: B-P/L-M test for autocorrelation

\begin{tabular}{|l|r|r|r|}
\hline \multicolumn{1}{|c|}{ Test } & Statistic & d.f. & Prob. \\
\hline Breusch-Pagan LM & 0.00481252 & 1 & 0.94469328 \\
\hline Pesaran scaled LM & -0.70370382 & & 0.48161724 \\
\hline Pesaran CD & -0.06937230 & & 0.94469328 \\
\hline
\end{tabular}

Source: Computed from regression results

The decision criteria for the B-P/L-M test involves studying the probability values. If greater than 0.05 , we fail to reject the null hypothesis that there is no autocorrelation. This is observable in the last column of the results table.

\subsubsection{Unit Root and Cointegration}

Unit roots cause non-stationarity in series, therefore must be tested for. A summary of unit root tests was obtained using E-Views. The null hypothesis stated that there is unit root in the series while the alternative hypothesis: no unit root in the series, meaning the series is stationary. All tests assumed asymptotic normality except probabilities for Fisher tests which were computed using an asymptotic Chi-square distribution. The Newey-West automatic bandwidth selection and Bartlett Kernel spectrum estimation ${ }^{6}$ were used to compute the summary of various unit root tests on the level of $\mathrm{F}$. The results are given in Table 2.

\footnotetext{
${ }^{1}$ Dickey, D. and Fuller, W. (1981). Likelihood Ratio Statistics for Autoregressive Time Series with a Unit Root. Econometrica.

${ }^{2}$ Phillips, P.C.B. and P. Perron (1988). Testing for Unit Roots in Autoregressive Moving Average Models with Unknown Order. Biometrica.

${ }^{3}$ Green, W.H. (2008).Econometric Analysis. $6^{\text {th }}$ Edition, Pearson Prentice Hall, Upper Saddle River.

${ }^{4}$ Micro panels have shorter time series and larger cross-sections, that is, fewer years in the panel.

${ }^{5}$ Pesaran, M.H. (2004). General Diagnostic Tests for Cross-section Dependence in Panels. Cambridge Working Papers in Economics.

Faculty of Economics, University of Cambridge.

${ }^{6}$ Newey, W and West, K.D. (1987). A Simple, Positive Semi-definite, Heteroscedasticity and Autocorrelation Consistent Covariance Matrix. Econometrica, Econometric Society.
} 
Table 2: Testing for unit root and cointegration

\begin{tabular}{|c|c|c|c|c|}
\hline Method & Statistic & Prob & Cross-sections & Obs \\
\hline \multicolumn{5}{|c|}{ Null: Unit Root (Assumes Common Unit Root Process) } \\
\hline Levin, Lin \& Chu t & -2.42435 & 0.0077 & 2 & 1080 \\
\hline \multicolumn{5}{|c|}{ Null: Unit Root (Assumes Individual Unit Root Process) } \\
\hline LM, Pesaran and Shin W-stat & -9.52002 & 0.0000 & 2 & 1080 \\
\hline ADF - Fisher Chi-square & 195.871 & 0.0000 & 2 & 1080 \\
\hline PP - Fisher Chi-square & 350.425 & 0.0000 & 2 & 1080 \\
\hline
\end{tabular}

The results shown in the table indicate probability values of less than 0.05 for each test, implying that we reject the null hypothesis and accept the alternative hypothesis that there is stationarity in the series.

2.4.2 Multicollinearity

Multicollinearity happens when multivariate analysis contains many variables that are significantly correlated. This can cause significant variables to appear statistically insignificant, so it should be corrected if it exists. There are two main ways of testing for multicollinearity: correlation coefficients and variance inflation factors. This paper applied correlation coefficients.

Data on variables used in this paper for the 47 Counties reported in 2007 and 2018 for the periods 2005/2006 and 2015/2016 were opened as a group to obtain the correlation matrix. The results were presented on the basis of the cross section identifiers: 2006 and 2016 as shown in Appendix 4. Conventionally, a correlation less than 0.5 indicates no multicollinearity while the opposite is the case. However, Gujarati (1995) posits that a correlation above 0.5 but below 0.84 indicates no serious multicollinearity.

The results show that multicollinearity is not widespread. However, it exists among the following variables: gender of household heads, food poverty rate and poverty severity rate (Appendix 4). This may be justified by the tendency of economic variables to move together. The need to reduce multicollinearity depends on how severe it is and the primary goal of the regression model. ${ }^{1}$ Moderate multicollinearity may not need to be resolved. If the presence of multicollinearity in some regressors does not affect either the predictions or the precision of the predictions, as well as goodness of fit, it does not need to be reduced ${ }^{2}$, like in our case where the economic variables are known to move together.

2.4.3 White Cross-section Method:

The white cross-section method was used to attain coefficient covariances for the pool. The method assumes that the errors are cross-sectionally correlated. The pool regression is treated as a multivariate regression with an equation for each cross-section, and computes robust standard errors for the system equations. Results were presented unstacked according to respective cross sections: 2006 and 2016 in Appendix 3.

\section{Analysis and Results}

\subsection{Pattern of Cash Transfer Expenditures}

Cash transfers are spent on food, education/school fees, health, investment/business, and other. Table 3 shows the share of cash transfers received from within Kenya by expenditure items. At the national level, education/school fees accounts for the largest share (44.6\%) followed by food $(33.5 \%)$, health $(6.9 \%)$, and investment/business $(4.5 \%)$ in that order. The expenditure category identified as "other," accounting for $10.5 \%$ of total cash transfer receipts, comprises rent/housing, clothing, debt repayment, etc. This is the category in which the so-called "temptation goods" such as alcohol, tobacco, and so on, would fall. Given that the category comprises many items and the total share is relatively small, expenditure on the temptation goods would be minor, if any at all.

These key priority expenditure patterns for the cash transfer received appear to negate the concern that cash transfers may be just "handouts" that promote purchase of alcohol, tobacco, or other so-called "temptation goods" in addition to leading to dependency. Table 3 also shows that female-headed households spend a higher proportion of cash transfers on food compared to male-headed households at the national level and in rural and urban areas. The male-headed households spend a higher proportion of the transfers on education/school fees and investment/business than their female-headed counterparts in all the three categories (national, rural and urban). Male-headed households spend more on health than female-headed households nationally and in rural areas while the opposite is the case in urban areas. Female-headed households tend to spend more on rent/housing, clothing, and debt repayment than male-headed households nationally and in the urban areas while in the rural areas maleheaded households spend slightly higher on the same items.

\footnotetext{
${ }^{1}$ Neter et.al. (1983). Applied Linear Regression Models. $4^{\text {th }}$ Edition.

${ }^{2}$ Weisberg, S. (2013). Applied Linear Regression. $4^{\text {th }}$ Edition. Regents of the University of Minnesota.
} 
Table 3: Percentage share of cash transfers by expenditure items

\begin{tabular}{|l|l|l|l|l|l|}
\hline Residence/Household Headship & Food & Education/School fees & Health & Investment/Business & Other \\
\hline National & $\mathbf{3 3 . 5}$ & $\mathbf{4 4 . 6}$ & $\mathbf{6 . 9}$ & $\mathbf{4 . 5}$ & $\mathbf{1 0 . 5}$ \\
Male-Headed & 29.0 & 50.7 & 5.8 & 5.0 & 9.5 \\
Female-Headed & 37.4 & 39.4 & 7.8 & 4.1 & 11.3 \\
\hline Rural & 38.9 & 38.2 & 7.0 & 4.2 & 11.7 \\
Male-Headed & 35.2 & 39.7 & 7.6 & 5.0 & 12.5 \\
Female-Headed & 41.8 & 37.0 & 6.6 & 3.6 & 11.0 \\
\hline Urban & $\mathbf{2 7 . 9}$ & $\mathbf{5 1 . 2}$ & $\mathbf{6 . 7}$ & $\mathbf{4 . 9}$ & $\mathbf{9 . 3}$ \\
Male-Headed & 23.3 & 60.7 & 4.2 & 5.0 & 6.8 \\
Female-Headed & 32.2 & 42.1 & 9.2 & 4.8 & 11.7 \\
\hline
\end{tabular}

Source: Kenya National Bureau of Statistics, Basic Report, 2015/16 Kenya Integrated Household Budget Survey, March 2018, p.137

\subsection{Determinants of Cash Transfer Expenditures}

As explained above, we used the pool object in E-Views to manage the cross section data for 47 Counties in Kenya. The E-Views 10 statistical package was used to run the regression and other statistical analyses. For the purpose of data analysis, dependent and independent variables used are described above.

\subsubsection{Analysis of the Regression Results}

For purpose of interpreting regression output, a probability value of 5\% (0.05) or less is generally accepted point at which to reject the null hypothesis. This implies that there is only a $5 \%$ chance that results would have come up in a random distribution. So it can be said with $95 \%$ probability of being correct that the variable is having some effect. This applies to the probability value for the whole model. The value is important because when there is multicollinearity among independent variables, coefficients of individual variables may be insignificant when the regression as a whole is significant. This is because highly correlated independent variables tend to explain the same part of variation in the dependent variable. For the purpose of interpretation, when:

- $\quad \mathrm{P}<0.001$ we have extremely strong evidence against the null hypothesis

- $0.001<\mathrm{P}<0.01$ we have strong evidence against the null hypothesis

- $0.01<\mathrm{P}<0.05$ we have rather strong evidence against the null hypothesis

- $0.05<\mathrm{P}<0.1$ we have some evidence against the null hypothesis

- $\quad \mathrm{P}>0.1$ we have no evidence against the null hypothesis

3.2.2 Regression of Cash Transfer Rate and the Independent Variables

This section of the regression analysis attempts to establish the general relationship between cash transfer rate (CTR) and determinants of cash transfer expenditures. The purpose is to determine the extent to which the cash transfer rate is influenced by the independent variables listed above.

The functional form of the regression is given as specified in section 2.2. Cross section pool objects estimation applied a simple model of the form:

\section{$C T R=f($ PSR, FPR, NUT, MALE, FEMALE, NONE, PRIMO, SECO, POSEC, RURAL, URBAN)}

The results are presented in the Table 4.

Table 4: Determinants of cash transfer

\begin{tabular}{|l|r|r|r|r|}
\hline \multicolumn{1}{|c|}{ Dependent Variable: CTR } & \multicolumn{3}{c|}{} \\
\hline \multicolumn{1}{|c|}{ C } & Coefficient & Std. Error & t-Statistic & Prob. \\
\hline PSR_2006 & 152.5296 & 76.97284 & 1.981603 & 0.0518 \\
\hline PSR_2016 & 0.051889 & 0.280663 & 0.184879 & 0.8539 \\
\hline FPR_2006 & 0.535785 & 1.523109 & 0.351770 & 0.7262 \\
\hline FPR_2016 & -2.403136 & 0.869955 & -2.762368 & 0.0075 \\
\hline NUT_2006 & 0.508534 & 0.681047 & 0.746695 & 0.4580 \\
\hline NUT_2016 & 0.383148 & 0.484333 & 0.791085 & 0.4318 \\
\hline NONE_2006 & -0.931244 & 0.491275 & -1.895568 & 0.0625 \\
\hline NONE_2016 & 2.250332 & 1.075536 & 2.092288 & 0.0404 \\
\hline PRIMO_2006 & -13.67434 & 16.57648 & -0.824924 & 0.4125 \\
\hline PRIMO_2016 & -0.056653 & 0.012285 & -4.611449 & 0.0000 \\
\hline SECO_2006 & 81.28627 & 65.57265 & 1.239637 & 0.2196 \\
\hline SECO_2016 & -2.261756 & 0.720799 & -3.137844 & 0.0026 \\
\hline POSEC_2006 & -95.77368 & 77.98974 & -1.228029 & 0.2239 \\
\hline POSEC_2016 & 7.590814 & 5.929831 & 1.280106 & 0.2051 \\
\hline MALE_2006 & -4.198450 & 97.28152 & -0.043158 & 0.9657 \\
\hline
\end{tabular}




\begin{tabular}{|l|r|r|r|r|}
\hline MALE_2016 & -118.8083 & 69.17743 & -1.717444 & 0.0907 \\
\hline FEMALE_2006 & 0.437878 & 0.985069 & 0.444515 & 0.6582 \\
\hline FEMALE_2016 & 100.5476 & 58.83455 & 1.708988 & 0.0923 \\
\hline RURAL_2006 & -0.169509 & 0.233331 & -0.726474 & 0.4702 \\
\hline RURAL_2016 & -0.242907 & 0.159617 & -1.521809 & 0.1330 \\
\hline URBAN_2006 & 0.702595 & 0.077180 & 9.103347 & 0.0000 \\
\hline URBAN_2016 & -0.277884 & 0.155990 & -1.781417 & 0.0796 \\
\hline \multicolumn{1}{|c|}{ AR(3) } & -0.183588 & 0.079385 & -2.312635 & 0.0240 \\
\hline R-Squared & 0.913778 & Mean Dependent Var & 60.64545 \\
\hline Adjusted R-Squared & 0.882792 & S.D. Dependent Var & 60.10152 \\
\hline S.E. Of Regression & 20.57619 & Sum Squared Resid & 27096.30 \\
\hline Log Likelihood & -373.5229 & F-Statistic & 29.48987 \\
\hline Durbin-Watson Stat & 2.073511 & Prob(F-Statistic) & 0.000000 \\
\hline
\end{tabular}

From the regression output summarized in Table 4, the general regression model which is AR (3) is significant with a probability value of 0.000000 . The output indicates that approximately $88 \%$ of changes in cash transfer rate are explained within the model. Accordingly, the following variables in the year 2006 significantly influenced cash transfer rate: food poverty rate, level of education (none, primary or secondary) and location in the urban area. This is shown by the probability values that are $\leq 0.05$.

3.2.3 Regression of expenditure Options and the Independent Variables

Reports show that individuals who benefit from cash transfers spend on food, education/school fees, health, investment/business, debt repayment, rent, and other. For the purpose of this section, data for 2016 was used for analysis. There was no available data reported on respective variables in 2006. This may be explained on the basis that this was the first household survey and that by the second survey, lessons learnt had been incorporated as well as more efficient methods and tools for data collection were used.

The purpose of this section is to establish whether cash transfer expenditure options were influenced by the various independent variables listed in the sections above. The analysis of regression on expenditure options for cash transfer recipients followed a model optimization criterion in ARMA $^{1}$ maximum likelihood assuming GaussNewton $^{2}$ innovations $(\mathrm{BHHH})^{3}$ using outer product of the gradient (OPG). The maximum likelihood estimation is preferred for its efficiency in terms of low variance estimates. It also follows that the Gaussian assumption in econometric analysis is considered reasonable. ARIMAX ${ }^{4}$ is one of the multivariate forecasting tools that support policy makers' decisions. The method consists of estimating the parameters in such a manner that the probability of observing the dependent variables is as high as possible, that is, finding maximum of the function.

Accordingly, it follows that if $\gamma=\beta_{0}+\beta_{1} X_{1}+\beta_{n} X_{n}+\mu_{i}$ with mean and variance; then a joint probability density function can be derived to take the form: $f\left(\gamma_{1} \ldots \gamma_{n} \mid \beta_{0}+\beta_{1} X_{1}+\beta_{n} X_{n}+\sigma^{2}\right)$ thus a likelihood function generally denoted as $\operatorname{LF}\left(\beta_{1}, \ldots \beta_{n}, \sigma^{2}\right)$.

While specifying the model, the log is used as a process of nullifying outliers in data and also to determine relevant percentage change in respective variables. The difference operator (d) was also used on some of the exogenous variables. Each expenditure option has a linear logarithmic (lin-log) regression function. The outputs are summarized below and interpretation criteria remain as was in part a) above.

3.2.3.1 Cash Transfer Expenditure on Food

The functional form of the model autoregressive is stated as:

$C T E_{-} F=f(P S R$, FPR, NUT, MALE, FEMALE, NONE, PRIMO, SECO, POSEC, RURAL, URBAN, CTR)

The results are presented in Table 5.

The general probability value $(0.000044)$ shows that the model is significant in determining cash transfer expenditure on food. It is established that the following variables influence decision to spend on food based on probability values that are $\leq 0.05$ : gender of the household head, food poverty rate, location of the household in the urban area as well as the cash transfer rate itself. The adjusted R- squared indicates that approximately $60 \%$ of decision to spend cash transfers on food is explained within the model as specified.

\footnotetext{
${ }^{1}$ Autoregressive Moving Average

2 The Gauss-Newton method is an iterative algorithm to solve nonlinear least squares problems.

3 "Berndt, Hall, Hall, Hausman"

${ }^{4}$ Autoregressive Moving Average with Explanatory Variable
} 
Table 5: Determinants of cash transfer expenditure on food

\begin{tabular}{|c|r|r|r|r|}
\hline \multicolumn{2}{|c|}{ Dependent Variable: Cash Transfer Expenditure on Food (CTE_F) } \\
\hline Variable & Coefficient & Std. Error & t-Statistic & Prob. \\
\hline C & 120.5382 & 60.53319 & 1.991275 & 0.0556 \\
\hline FEMALE_2016 & -116.2108 & 35.58957 & -3.265305 & 0.0027 \\
\hline FPR_2016 & -1.678616 & 0.570465 & -2.942542 & 0.0062 \\
\hline MALE_2016 & 135.8140 & 43.23242 & 3.141484 & 0.0038 \\
\hline NONE_2016 & -17.56129 & 12.13535 & -1.447119 & 0.1582 \\
\hline DLOG(NUT_2016) & 2.283542 & 2.405628 & 0.949250 & 0.3501 \\
\hline POSEC_2016 & -31.51022 & 45.43526 & -0.693519 & 0.4933 \\
\hline PRIMO_2016 & 128.4126 & 66.33939 & 1.935692 & 0.0624 \\
\hline PSR_2016 & 1.144535 & 1.003334 & 1.140731 & 0.2630 \\
\hline RURAL_2016 & -0.164802 & 0.113436 & -1.452813 & 0.1567 \\
\hline SECO_2016 & -153.3322 & 78.87309 & -1.944036 & 0.0613 \\
\hline URBAN_2016 & -0.300288 & 0.131614 & -2.281576 & 0.0298 \\
\hline CTR_2016 & 0.233618 & 0.113755 & 2.053689 & 0.0488 \\
\hline AR(3) & 0.538668 & 0.188885 & 2.851829 & 0.0078 \\
\hline MA(4) & 0.506529 & 0.295688 & 1.713050 & 0.0970 \\
\hline SIGMASQ & 65.81259 & 19.20057 & 3.427637 & 0.0018 \\
\hline R-squared & 0.729797 & Mean dependent var & 36.29783 \\
\hline Adjusted R-squared & 0.594696 & S.D. dependent var & 15.77911 \\
\hline S.E. of regression & 10.04553 & Akaike info criterion & & 7.768946 \\
\hline Sum of squared residuals & 3027.379 & Schwarz criterion & 8.404995 \\
\hline Log likelihood & -162.6858 & Hannan-Quinn criter. & 8.007214 \\
\hline F-statistic & 5.401855 & Durbin-Watson stat & 2.167190 \\
\hline Prob(F-statistic) & 0.000044 & & & \\
\hline Appendx & & & & \\
\hline
\end{tabular}

Appendix 1 corroborates the finding on the influence of food poverty rate on cash transfer expenditure on food at the county level. It shows, with a few exceptions, that counties with higher food poverty headcount rates tend to spend higher shares of the cash transfer receipts on food than their counterparts with lower food poverty headcount rates. Further details are given in Appendix 2. For example, out of the 11 counties with the highest overall severity of poverty ratings, eight spent between $41.7 \%$ and $72.7 \%$ of the cash transfer receipts on food. Two spent about 33\% and one (West Pokot) 10.9\%. West Pokot spent $70.8 \%$ on education/school fees, an investment in human capital. The county with the highest overall severity of poverty rating, Turkana, spent about $59.3 \%$ of the cash transfers on food while the one with the second highest rating, Mandera, spent $72.7 \%$ on food. The three counties (Tharaka-Nithi, Nyeri, and Kirinyaga) with the lowest overall severity of poverty rating spent $21.3 \%, 32.1 \%$, and $25.9 \%$ on food, respectively.

\subsubsection{Cash Transfer Expenditure on Education or Fees}

The functional form of the model is stated as:

$C T E \_E D=f(P S R$, FPR, NUT, MALE, FEMALE, NONE, PRIMO, SECO, POSEC, RURAL, URBAN, CTR)

The results are presented in Table 6 .

The general probability value $(0.000336)$ shows that the model is overall significant in determining cash transfer expenditure on education. It is established that the following variables significantly influence decision to spend on education based on probability values that are $\leq 0.05$ : food poverty rate, poverty severity rate and location of the household (rural and urban). Changes in cash transfer rate also significantly influence expenditure on education according to the regression output. The adjusted R- squared indicates that approximately $51 \%$ of decision to spend cash transfers on education is explained within the model as specified. 
Table 6: Determinants of cash transfer expenditure on education/fees

\begin{tabular}{|c|r|r|r|r|}
\hline \multicolumn{2}{|c|}{ Dependent Variable: Cash Transfer Expenditure on Education (CTE_ED) } \\
\hline Cariable & Coefficient & Std. Error & t-Statistic & Prob. \\
\hline FEMALE_2016 & -170.4588 & 48.07645 & -3.545578 & 0.0013 \\
\hline LOG(FPR_2016) & 68.67398 & 39.26971 & 1.748777 & 0.0902 \\
\hline MALE_2016 & 23.97647 & 11.19266 & 2.142160 & 0.0401 \\
\hline NONE_2016 & -81.34303 & 45.35256 & -1.793571 & 0.0826 \\
\hline DLOG(NUT_2016) & 12.64436 & 12.99986 & 0.972654 & 0.3383 \\
\hline POSEC_2016 & 2.123781 & 3.300281 & 0.643515 & 0.5246 \\
\hline PRIMO_2016 & 4.187821 & 72.50353 & 0.057760 & 0.9543 \\
\hline DLOG(PSR_2016) & -81.07661 & 43.19125 & -1.877154 & 0.0699 \\
\hline RURAL_2016 & -16.01411 & 4.282173 & -3.739715 & 0.0007 \\
\hline SECO_2016 & 0.289064 & 0.106644 & 2.710560 & 0.0108 \\
\hline URBAN_2016 & 97.99201 & 51.38624 & 1.906970 & 0.0658 \\
\hline DLOG(CTR_2016) & 0.382220 & 0.099425 & 3.844325 & 0.0006 \\
\hline AR(2) & 2.356782 & 2.951783 & 0.798426 & 0.4307 \\
\hline SIGMASQ & 0.531827 & 0.220486 & 2.412072 & 0.0220 \\
\hline R-squared & 92.86338 & 30.79859 & 3.015183 & 0.0051 \\
\hline Adjusted R-squared & 0.661146 & Mean dependent var & 38.95848 \\
\hline S.E. of regression & 0.508115 & S.D. dependent var & 16.73742 \\
\hline Sum of squared residuals & 11.73871 & Akaike info criterion & 8.035635 \\
\hline Log likelihood & 4271.715 & Schwarz criterion & 8.631931 \\
\hline F-statistic & -169.8196 & Hannan-Quinn criter. & 8.259011 \\
\hline Prob(F-statistic) & 4.320339 & Durbin-Watson stat & 1.961431 \\
\hline 3.2.3 & 0.000336 & & \\
\hline
\end{tabular}

3.2.3.3 Cash Transfer Expenditure on Health

The functional form of the model is stated as:

$C T E_{-} H=f($ PSR, FPR, NUT, MALE, FEMALE, NONE, PRIMO, SECO, POSEC, RURAL, URBAN, CTR)

The results are presented in Table 7.

The general probability value $(0.070290)$ shows that the model is relatively significant in determining cash transfer expenditure on health as reiterated by adjusted R-squared of approximately $20 \%$. It is established that the following variables significantly influence decision to spend on health based on probability values that are $\leq 0.05$ : changes in poverty severity rate and level of education (primary, secondary and post-secondary). Regression output indicates that cash transfer rate does not significantly influence expenditure on health. The results also show that nutritional status does not have a significant influence on expenditure on health, contrary to our expectation.

Table 7: Determinants of cash transfer expenditure on health

\begin{tabular}{|c|r|r|r|r|}
\hline \multicolumn{2}{|c|}{ Dependent Variable: Cash Transfer Expenditure on Health (CTE_H) } \\
\hline Variable & \multicolumn{1}{c|}{ Coefficient } & Std. Error & t-Statistic & Prob. \\
\hline C & 56.27545 & 28.19412 & 1.995999 & 0.0542 \\
\hline FEMALE_2016 & -20.18127 & 20.58483 & -0.980395 & 0.3340 \\
\hline FPR_2016 & -0.084786 & 0.230811 & -0.367339 & 0.7157 \\
\hline MALE_2016 & 24.82162 & 23.96418 & 1.035780 & 0.3078 \\
\hline D(NONE_2016) & 0.005548 & 0.014488 & 0.382938 & 0.7042 \\
\hline DLOG(NUT_2016) & 2.111044 & 1.195982 & 1.765113 & 0.0868 \\
\hline POSEC_2016 & -47.02198 & 22.90221 & -2.053163 & 0.0481 \\
\hline PRIMO_2016 & 35.50185 & 17.53194 & 2.024982 & 0.0510 \\
\hline LOG(PSR_2016) & -18.80212 & 9.579102 & -1.962827 & 0.0581 \\
\hline RURAL_2016 & 0.031620 & 0.048218 & 0.655779 & 0.5165 \\
\hline SECO_2016 & -42.13650 & 20.88918 & -2.017145 & 0.0519 \\
\hline URBAN_2016 & -0.008022 & 0.051023 & -0.157231 & 0.8760 \\
\hline CTR_2016 & -0.032210 & 0.062426 & -0.515968 & 0.6093 \\
\hline R-squared & 0.409701 & Mean dependent var & 8.093478 \\
\hline Adjusted R-squared & 0.195047 & S.D. dependent var & 6.571163 \\
\hline S.E. of regression & 5.895592 & Akaike info criterion & 6.619370 \\
\hline Sum of squared residuals & 1147.014 & Schwarz criterion & 7.136160 \\
\hline Log likelihood & -139.2455 & Hannan-Quinn criter. & 6.812963 \\
\hline F-statistic & 1.908659 & Durbin-Watson stat & 2.270053 \\
\hline Prob(F-statistic) & 0.070290 & & \\
\hline
\end{tabular}




\subsubsection{Cash Transfer Expenditure on Investment}

The functional form of the model is stated as:

$C T E_{-} I N V=f(P S R, F P R$, NUT, MALE, FEMALE, NONE, PRIMO, SECO, POSEC, RURAL, URBAN, CTR)

The results are presented in Table 8 .

The general probability value $(0.032633)$ shows that the model is overall significant in determining cash transfer expenditure on investment. The model seeks to establish whether changes in food poverty rate, poverty severity rate, nutrition level and cash transfer rate would affect expenditure on investment. It is established that the following variables significantly influence decision to spend on investment based on probability values that are $\leq .05$ : nutrition, location of the household in the rural areas (urban to a small extent). Changes in cash transfer rate have a relatively insignificant influence on expenditure on investment according to the regression output. The adjusted R- squared indicates that approximately $27 \%$ of decision to spend cash transfers on investment is explained within the model as specified.

Table 8: Determinants of cash transfer expenditure on investment

\begin{tabular}{|c|c|c|c|c|}
\hline \multicolumn{5}{|c|}{ Dependent Variable: Cash Transfer Expenditure on Investment (CTE_INV) } \\
\hline Variable & Coefficient & Std. Error & t-Statistic & Prob. \\
\hline $\mathbf{C}$ & 105.4160 & 39.63882 & 2.659413 & 0.0123 \\
\hline FEMALE_2016 & 58.30226 & 35.44050 & 1.645075 & 0.1101 \\
\hline DLOG(FPR_ 2016) & 3.038798 & 7.947263 & 0.382370 & 0.7048 \\
\hline MALE_2016 & -67.21497 & 41.13966 & -1.633824 & 0.1124 \\
\hline NONE_2016 & -8.197390 & 9.917358 & -0.826570 & 0.4148 \\
\hline NUT_ 2016 & -0.595488 & 0.245230 & -2.428284 & 0.0212 \\
\hline POSEC_2016 & 84.81443 & 51.62605 & 1.642861 & 0.1105 \\
\hline PRIMO_2016 & -15.40011 & 30.31742 & -0.507962 & 0.6151 \\
\hline DLOG(PSR_2016) & -0.939626 & 7.043897 & -0.133396 & 0.8947 \\
\hline RURAL_2016 & -0.229368 & 0.075374 & -3.043063 & 0.0047 \\
\hline SECO_2016 & 17.74235 & 36.07707 & 0.491790 & 0.6263 \\
\hline URBAN_2016 & -0.175339 & 0.090359 & -1.940484 & 0.0615 \\
\hline CTR_2016 & -0.016444 & 0.104685 & -0.157076 & 0.8762 \\
\hline AR(5) & 0.519576 & 0.266753 & 1.947777 & 0.0605 \\
\hline SIGMASQ & 31.68027 & 8.853284 & 3.578364 & 0.0012 \\
\hline R-squared & 0.499231 & \multicolumn{2}{|c|}{ Mean dependent var } & 5.273913 \\
\hline Adjusted R-squared & 0.273077 & \multicolumn{2}{|c|}{ S.D. dependent var } & 8.041709 \\
\hline S.E. of regression & 6.856343 & \multicolumn{2}{|c|}{ Akaike info criterion } & 6.979947 \\
\hline Sum of squared residuals & 1457.293 & \multicolumn{2}{|l|}{ Schwarz criterion } & 7.576243 \\
\hline Log likelihood & -145.5388 & \multicolumn{2}{|c|}{ Hannan-Quinn criter. } & 7.203323 \\
\hline F-statistic & 2.207484 & \multicolumn{2}{|c|}{ Durbin-Watson stat } & 2.018237 \\
\hline Prob(F-statistic) & 0.032633 & & & \\
\hline
\end{tabular}

\subsubsection{Cash Transfer Expenditure for Loan and/or Debt Repayment}

The functional form of the model is stated as:

\section{$C T E_{-} D B T=f(P S R$, FPR, NUT, MALE, FEMALE, NONE, PRIMO, SECO, POSEC, RURAL, URBAN, CTR)}

The results are presented in Table 9.

The general probability value $(0.006420)$ shows that the model is overall significant in determining cash transfer expenditure on loan or debt repayment. The model seeks to establish whether changes in food poverty rate, nutrition level, poverty severity rate and cash transfer rate, would affect expenditure on loan or debt repayment. It is established that only changes in nutrition level $(\mathrm{P}=0.0047)$ affect cash transfer expenditure on loan or debt repayment. Changes in cash transfer rate have a relatively insignificant influence expenditure on loan or debt repayment according to the regression output. The adjusted R- squared indicates that approximately $39 \%$ of decision to spend cash transfers on loan or debt repayment is explained within the model as specified. 
Table 9: Determinants of cash transfer expenditure on loan and/or debt repayment

\begin{tabular}{|c|c|c|c|c|}
\hline \multicolumn{5}{|c|}{ Dependent Variable: Cash Transfer Expenditure on Debt/ Loan Repayment (CTE_DBT) } \\
\hline Variable & Coefficient & Std. Error & t-Statistic & Prob. \\
\hline $\mathbf{C}$ & 16.54189 & 8.659027 & 1.910364 & 0.0657 \\
\hline FEMALE 2016 & 0.628736 & 0.344349 & 1.825870 & 0.0778 \\
\hline LOG(FPR_2016) & -5.954008 & 3.735325 & -1.593973 & 0.1214 \\
\hline D(MALE_2016) & -0.550046 & 0.655714 & -0.838851 & 0.4082 \\
\hline NONE_ 2016 & 5.145697 & 3.707371 & 1.387964 & 0.1754 \\
\hline DLOG(NUT_2016) & 2.225762 & 0.728889 & 3.053635 & 0.0047 \\
\hline POSEC_2016 & -22.27327 & 26.41743 & -0.843128 & 0.4058 \\
\hline PRIMO_2016 & -13.82546 & 15.43407 & -0.895775 & 0.3775 \\
\hline DLOG(PSR 2016) & 2.918817 & 6.602269 & 0.442093 & 0.6616 \\
\hline D(RURAL_2016) & 0.009062 & 0.015701 & 0.577166 & 0.5681 \\
\hline SECO_2016 & 16.88320 & 18.38135 & 0.918496 & 0.3657 \\
\hline URBAN_2016 & -0.029860 & 0.023917 & -1.248475 & 0.2215 \\
\hline DLOG(CTR_2016) & 0.959518 & 0.829333 & 1.156976 & 0.2564 \\
\hline $\mathrm{AR}(2)$ & -1.000000 & 0.000749 & -1335.194 & 0.0000 \\
\hline МA(4) & -0.999994 & $8.53 \mathrm{E}-05$ & -11717.11 & 0.0000 \\
\hline SIGMASQ & 6.054896 & 2.769087 & 2.186604 & 0.0367 \\
\hline R-squared & 0.591385 & \multicolumn{2}{|c|}{ Mean dependent var } & 1.456522 \\
\hline Adjusted R-squared & 0.387078 & \multicolumn{2}{|c|}{ S.D. dependent var } & 3.891966 \\
\hline S.E. of regression & 3.046994 & \multicolumn{2}{|c|}{ Akaike info criterion } & 5.516525 \\
\hline Sum of squared residuals & 278.5252 & \multicolumn{2}{|l|}{ Schwarz criterion } & 6.152574 \\
\hline Log likelihood & -110.8801 & \multicolumn{2}{|c|}{ Hannan-Quinn criter. } & 5.754793 \\
\hline F-statistic & 2.894588 & \multicolumn{2}{|c|}{ Durbin-Watson stat } & 1.945812 \\
\hline Prob(F-statistic) & 0.006420 & & & \\
\hline
\end{tabular}

3.2.3.6 Cash Transfer Expenditure on Rent

The functional form of the model is stated as:

\section{$C T E \_R N T=f($ PSR, FPR, NUT, MALE, FEMALE, NONE, PRIMO, SECO, POSEC, RURAL, URBAN, CTR)}

The results are presented in Table 10 .

The general probability value $(0.087119)$ shows that the model is relatively significant in explaining cash transfer expenditure on rent. The model seeks to establish whether changes in food poverty rate, poverty severity rate, location in urban area and cash transfer rate, would affect expenditure on rent. It is established that the following variables explain decision to spend on rent by their probability values that are $\leq 0.05$ : change in food poverty rate, nutrition and change in poverty severity rate. Changes in cash transfer rate relatively insignificantly influence expenditure on rent, according to the regression output. Contrary to our expectation, results of our analysis shows that location of the household (urban or rural) does not influence cash transfer expenditure on rent. The adjusted R-squared indicates that approximately $21 \%$ of decision to spend cash transfers on rent is explained within the model as specified. 
Table 10: Determinants of cash transfer expenditure on rent

\begin{tabular}{|c|r|r|r|r|}
\hline \multicolumn{2}{|c|}{ Dependent Variable: Cash Transfer Expenditure on Rent/ Housing (CTE_RNT) } \\
\hline Variable & Coefficient & Std. Error & t-Statistic & Prob. \\
\hline C & -31.57117 & 9.895327 & -3.190513 & 0.0033 \\
\hline FEMALE_2016 & -6.777931 & 3.926972 & -1.725994 & 0.0946 \\
\hline LG(FPR_2016) & 6.508463 & 1.226411 & 5.306918 & 0.0000 \\
\hline MALE_2016 & 7.273471 & 4.525386 & 1.607260 & 0.1185 \\
\hline NONE_2016 & -1.035061 & 2.180645 & -0.474658 & 0.6385 \\
\hline POSEC_2016 & 0.119613 & 0.060388 & 1.980722 & 0.0569 \\
\hline PRIMO_2016 & 6.044171 & 9.268311 & 0.652133 & 0.5193 \\
\hline DLOG(PSR_2016) & 1.923791 & 7.068231 & 0.272174 & 0.7874 \\
\hline D(RURAL_2016) & -2.179538 & 0.555265 & -3.925221 & 0.0005 \\
\hline SECO_2016 & 0.007052 & 0.005293 & 1.332233 & 0.1928 \\
\hline LOG(URBAN_2016) & -2.513195 & 8.444353 & -0.297618 & 0.7680 \\
\hline DLOG(CTR_2016) & 3.003869 & 1.946304 & 1.543371 & 0.1332 \\
\hline AR(2) & 0.336734 & 0.332712 & 1.012090 & 0.3196 \\
\hline MA(5) & 0.679771 & 0.161996 & 4.196220 & 0.0002 \\
\hline SIGMASQ & 0.656611 & 0.258494 & 2.540143 & 0.0165 \\
\hline R-squared & 1.489800 & 0.506023 & 2.944132 & 0.0062 \\
\hline Adjusted R-squared & 0.471007 & Mean dependent var & 0.660870 \\
\hline S.E. of regression & 0.206511 & S.D. dependent var & 1.696726 \\
\hline Sum of squared residuals & 1.511410 & Akaike info criterion & 4.017615 \\
\hline Log likelihood & 68.53079 & Schwarz criterion & 4.653664 \\
\hline F-statistic & -76.40515 & Hannan-Quinn criter. & 4.255883 \\
\hline Prob (F-statistic) & 1.780770 & Durbin-Watson stat & 1.993364 \\
\hline S.3. & 0.087119 & & & \\
\hline
\end{tabular}

3.2.3.7 Cash Transfer Expenditure on Other Items

The functional form of the model is stated as:

\section{$C T E_{\text {other }}=f($ PSR, FPR, NUT, MALE, FEMALE, NONE, PRIMO, SECO, POSEC, RURAL, URBAN, CTR)}

The results are presented in Table 11 .

The regression output above indicates that cash transfer expenditure on other items is mainly influenced by poverty severity rate and changes in cash transfer rate. However, only approximately $3 \%$ of variations in decisions to spend on other items is explained within this model, as shown by adjusted R- squared.

Table 11: Determinants of cash transfer expenditure on other items

\begin{tabular}{|c|r|r|r|r|}
\hline & \multicolumn{5}{|c|}{ Dependent Variable: CTE_OTHR } & t-Statistic & Prob. \\
\hline Variable & Coefficient & Std. Error & 3.204089 & 0.0031 \\
\hline CEMALE_2016 & 71.65269 & 22.36289 & 0.565307 & 0.5759 \\
\hline DLOG(FPR_2016) & 10.52580 & 18.61961 & 1.713845 & 0.0965 \\
\hline MALE_2016 & 4.607031 & 2.688126 & -0.744830 & 0.4620 \\
\hline NONE_2016 & -16.52043 & 22.18012 & -0.062870 & 0.9503 \\
\hline DLOG(NUT_2016) & -0.419110 & 6.666269 & -0.478273 & 0.6358 \\
\hline POSEC_2016 & -0.661795 & 1.383718 & -0.342178 & 0.7345 \\
\hline PRIMO_2016 & -10.66671 & 31.17302 & 0.485811 & 0.6305 \\
\hline PSR_2016 & 13.00182 & 26.76313 & 2.202978 & 0.0352 \\
\hline RURAL_2016 & 1.140163 & 0.517556 & -1.499587 & 0.1438 \\
\hline SECO_2016 & -0.066526 & 0.044363 & -0.518537 & 0.6078 \\
\hline URBAN_2016 & -16.52403 & 31.86663 & -1.230414 & 0.2278 \\
\hline LOG(CTR_2016) & -0.058548 & 0.047584 & -3.890194 & 0.0005 \\
\hline AR(2) & -6.487926 & 1.667764 & 1.697678 & 0.0996 \\
\hline SIGMASQ & 0.384360 & 0.226403 & 3.296069 & 0.0025 \\
\hline R-squared & 28.68552 & 8.702949 & & 11.38696 \\
\hline Adjusted R-squared & 0.330543 & Mean dependent var & 6.618244 \\
\hline S.E. of regression & 0.028208 & S.D. dependent var & 6.853394 \\
\hline Sum of squared residual & 6.524233 & Akaike info criterion & 7.449690 \\
\hline Log likelihood & 1319.534 & Schwarz criterion & & 7.076770 \\
\hline F-statistic & -142.6281 & Hannan-Quinn criter. & & 1.955536 \\
\hline Prob (F-statistic) & 1.093301 & Durbin-Watson stat & & \\
\hline
\end{tabular}




\section{Conclusions}

Our findings show that unconditional cash transfers are spent on food, education/school fees, health, investment/business, rent/housing, clothing, debt repayment, and other. Overall, households in Kenya seem to make "sensible" decisions in their expenditure of such income. They spend the money on items that are in line with their socioeconomic situation. The highest proportion of such income is spent on education which they consider as investment in human capital of their children. Next is expenditure on food and the pattern is consistent with our prior expectations - poverty severity rates and food poverty have significant influence on how the unconditional cash transfers are spent. Such income augments households' assets, consumption, food security and investment in the education of their children. Expenditures on temptation goods, such as alcohol and tobacco must be very small, if any. Such expenditures would fall under the category identified as "other," accounting for $10.5 \%$ of total cash transfer receipts and comprises rent/housing, clothing, debt repayment, etc. Given that the category's share is small and the category is composed of a number of items, expenditure on tobacco and alcohol, if any, would be very small.

At the national level, education/school fees accounts for the largest share (44.6\%) followed by food (33.5\%), health $(6.9 \%)$, and investment/business $(4.5 \%)$ in that order. These key priority expenditure patterns for the cash transfer received appear to negate the concern that cash transfers may be just "handouts" that promote purchase of alcohol, tobacco, or other so-called "temptation goods" in addition to leading to dependency. Factors that influence how the recipients spend the cash include the household's poverty severity rating, food poverty rating, location (urban or rural), nutritional status and gender and education level of head of household. They are summarized below.

Determinants of cash transfer rates: The following variables in the year 2006 significantly influenced cash transfer rate: food poverty rate, level of education (none, primary or secondary) and location in the urban area. This is shown by the probability values that are $\leq 0.05$.

Cash transfer expenditure on food: This study established that the following variables influence decision to spend on food based on probability values that are $\leq 0.05$ : gender of the household head, food poverty rate, location of the household in the urban area as well as the cash transfer rate itself. Aside from a few exceptions, counties with higher food poverty headcount rates tend to spend higher shares of the cash transfer receipts on food than their counterparts with lower food poverty headcount rates.

Cash transfer expenditure on education/school fees: We established that the following variables significantly influence decision to spend on education based on probability values that are less than or equal to 0.05: food poverty rate, poverty severity rate and location of the household (rural and urban).

Cash transfer expenditure on health: We also established that the following variables significantly influence decision to spend on health based on probability values that are $\leq 0.05$ : changes in poverty severity rate and level of education (primary, secondary and post-secondary). Contrary to our expectation, the results of the analysis show that nutritional status does not have a significant influence on expenditure on health.

Cash transfer expenditure on investment: We also ascertained that the following variables significantly influence decision to spend on investment based on probability values that are $\leq 0.05$ : nutrition, location of the household in the rural areas (urban to a small extent). Changes in cash transfer rate have a relatively insignificant influence on expenditure on investment according to the regression output.

Cash transfer expenditure on loan and/or debt repayment: We found that only changes in nutrition level $(\mathrm{P}=$ 0.0047) affect cash transfer expenditure on loan or debt repayment. Changes in cash transfer rate have a relatively insignificant influence expenditure on loan or debt repayment according to the regression output. In any case, only approximately $39 \%$ of decision to spend cash transfers on loan or debt repayment is explained within the model as specified.

Cash transfer expenditure on rent: It is established that the following variables explain decision to spend on rent by their probability values that are $\leq 0.05$ : change in food poverty rate, nutrition and change in poverty severity rate. Changes in cash transfer rate relatively insignificantly influence expenditure on rent. Contrary to our expectation, results of our analysis show that location of the household (urban or rural) does not influence cash transfer expenditure on rent.

\section{Recommendations}

In light of the above findings, when planning and executing government's social protection programmes, the recipients should be given greater say than has been the case hitherto. Donors, corporate and NGO sectors should also consider supporting unconditional cash transfer programmes. The beneficiaries should be given lee-way in deciding on how to spend the money, especially in disruptive times. This would improve effectiveness and sustainability of such programmes. Additionally, there is need to embrace non-physical means of transferring funds to beneficiaries such as use of mobile money transfers like Mpesa as opposed to cash payments. This is particularly relevant during periods of disruptions like COVID-19. Furthermore, the government and food-aid agencies should adopt the idea of food relief in the form of unconditional cash transfer as one of the delivery mechanisms. This 
would ensure timely delivery of aid to the needy.

\section{References}

1. Baird, S, Ferreira, F H G, Özler, B and Woolcock, M (2014). "Conditional, Unconditional and Everything in between: A Systematic Review of the Effects of Cash Transfer Programmes on Schooling Outcomes", Journal of Development Effectiveness 6 (1). doi:10.1080/19439342.2014.890362.

2. Bosworth, J. et al., (2016). The Cash Transfer Programme for Orphans and Vulnerable Children: The Catalyst for Cash Transfer in Kenya in Davis, B. et al.(Editors). From Evidence to Action: The Story of Cash Transfers and Impact Evaluation in Sub-Saharan Africa, The Food and Agriculture Organization of the United Nations and The United Nations Children's Fund and Oxford University Press.

3. Davis, B. et al. (Editors), (2016). From Evidence to Action: The Story of Cash Transfers and Impact Evaluation in Sub-Saharan Africa, The Food and Agriculture Organization of the United Nations and The United Nations Children's Fund and Oxford University Press.

4. Dickey, D. and Fuller, W. (1981). Likelihood Ratio Statistics for Autoregressive Time Series with a Unit Root. Econometrica.

5. Green, W.H. (2008). Econometric Analysis. $6^{\text {th }}$ Edition. Pearson Prentice Hall, Upper Saddle River.

6. Gujarati, D.N. (1995). Basic Econometrics. $4^{\text {th }}$ Edition, United States Military Academy, New York.

7. Haushofer, J., Miguel, E., Niehaus, P. and Walker, M. (2019). The impact of unconditional cash transfers on general welfare in Kenya. Featured in "The Economist." An Ipa study.

8. HelpAge International (2004). Social protection for older Kenyans: Options for implementing the national social protection policy. Pension Watch.

9. Ikiara, G. K. (August 2009). Political Economy of Cash Transfers in Kenya: A Report prepared for the Overseas Development Institute.

10. Klein, Michael, and Colin Mayer (May 2011). "Mobile Banking and Financial Inclusion: The regulatory lessons" World Bank Policy Research Working Paper 5664.

11. Kutner, M. H. et al. (2005). Applied Linear Statistical Models, $5^{\text {th }}$ Edition, McGraw-Hill/Irwin Series Operations and Decision Sciences, New York.

12. Manley, James et al. (2012). How Effective are Cash Transfer Programmes at Improving Nutritional Status? A Rapid Evidence Assessment of Programmes' Effects on Anthropometric Outcomes, London: EPPI-Centre, Social Science Research Unit, Institute of Education, University of London, London.

13. Onyango-Ouma, W., and Fiona Samuels (2012). "Transforming Cash Transfers: Beneficiary and Community Perspectives on the Cash Transfer for Orphans and Vulnerable Children Programme in Kenya." London, UK, and Nairobi, Kenya. (Cited in WB study).

14. Pedroni, P. (1999). "Critical Values for Cointegration Tests in Heterogeneous Panels with Multiple Regressors," Oxford Bulletin of Economics and Statistics, 61, 653-70.

15. Pedroni, P. (2004). "Panel Cointegration; Asymptotic and Finite Sample Properties of Pooled Time Series Tests with an Application to the PPP Hypothesis," Econometric Theory, 20, 597-625.

16. Phillips, P.C.B. and Perron (1988). Testing for Unit Roots in Autoregressive Moving Average Models with Unknown Order. Biometrika.

17. Republic of Kenya (2007). Kenya National Bureau of Statistics. 2005/06 Kenya Integrated Household Budget Survey, Government Printer, Nairobi.

18. Republic of Kenya (2011). The old persons cash transfer program operations manual. Nairobi, Kenya: Ministry of Gender, Children and Social Development in cooperation with HelpAge International.

19. Republic of Kenya (March 2018). Kenya National Bureau of Statistics. 2015/16 Kenya Integrated Household Budget Survey, Government Printer, Nairobi.

20. Republic of Kenya (March 2018). Kenya National Bureau of Statistics. Basic Report 2015/16 Kenya Integrated Household Budget Survey, Government Printer, Nairobi.

21. Weisberg, S. (2013). Applied Linear Regression. $4^{\text {th }}$ Edition. Regents of the University of Minnesota. 
Vol.13, No.4, 2022

\section{APPENDICES}

Appendix 1: Food poverty estimates (individual) and share of cash transfers spent on food by county, 2015/16

\begin{tabular}{|c|c|c|}
\hline National/County & Food Poverty Headcount Rate \% & $\begin{array}{l}\text { Share of Cash Transfers Received } \\
\text { Within the Country Spent on } \\
\text { Food \% }\end{array}$ \\
\hline National & 32.0 & 33.5 \\
\hline Mombasa & 23.6 & 20.3 \\
\hline Kwale & 41.1 & 36.6 \\
\hline Kilifi & 48.4 & 51.8 \\
\hline Tana River & 55.4 & 44.0 \\
\hline Lamu & 19.9 & 50.0 \\
\hline Taita/Taveta & 38.9 & 42.0 \\
\hline Garissa & 45.2 & 50.0 \\
\hline Wajir & 41.3 & 59.4 \\
\hline Mandera & 61.9 & 72.7 \\
\hline Marsabit & 55.6 & 60.8 \\
\hline Isiolo & 34.2 & 48.6 \\
\hline Meru & 15.5 & 46.5 \\
\hline Tharaka-Nithi & 31.2 & 21.3 \\
\hline Embu & 28.3 & 36.1 \\
\hline Kitui & 39.4 & 43.2 \\
\hline Machakos & 24.1 & 46.6 \\
\hline Makueni & 30.7 & 55.8 \\
\hline Nyandarua & 29.8 & 27.7 \\
\hline Nyeri & 15.5 & 32.1 \\
\hline Kirinyaga & 18.8 & 25.9 \\
\hline Murang'a & 22.7 & 40.6 \\
\hline Kiambu & 23.5 & 30.4 \\
\hline Turkana & 66.1 & 59.3 \\
\hline West Pokot & 57.3 & 10.9 \\
\hline Samburu & 60.1 & 33.6 \\
\hline Trans Nzoia & 33.3 & 13.3 \\
\hline Uasin Gishu & 38.2 & 21.8 \\
\hline Elgoyo/Marakwet & 44.8 & 22.2 \\
\hline Nandi & 31.5 & 17.6 \\
\hline Baringo & 41.4 & 27.1 \\
\hline Laikipia & 28.5 & 33.2 \\
\hline Nakuru & 19.6 & 36.8 \\
\hline Narok & 22.1 & 42.0 \\
\hline Kajiado & 36.9 & 8.2 \\
\hline Kericho & 31.4 & 16.9 \\
\hline Bomet & 32.8 & 58.6 \\
\hline Kakamega & 33.3 & 33.6 \\
\hline Vihiga & 36.6 & 48.2 \\
\hline Bungoma & 32.4 & 38.3 \\
\hline Busia & 59.5 & 41.7 \\
\hline Siaya & 27.3 & 55.1 \\
\hline Kisumu & 32.5 & 8.7 \\
\hline Homa Bay & 22.7 & 28.1 \\
\hline Migori & 32.0 & 38.3 \\
\hline Kisii & 44.5 & 12.4 \\
\hline Nyamira & 36.3 & 27.7 \\
\hline Nairobi City & 16.1 & 14.0 \\
\hline
\end{tabular}

Source: Computed from KIHBS data 
Appendix 2: Overall poverty estimates by severity of poverty and proportion of cash transfers spent on food by county

\begin{tabular}{|c|c|c|c|c|c|}
\hline $\begin{array}{l}\text { Poverty } \\
\text { Category } \\
(\%)\end{array}$ & County & $\begin{array}{l}\text { No. of } \\
\text { counties }\end{array}$ & $\begin{array}{l}\text { Share of } \\
\text { Food } \\
\text { Expenditure } \\
(\%)\end{array}$ & County & $\begin{array}{l}\text { No. of } \\
\text { counties }\end{array}$ \\
\hline $0.5-1.0$ & $\begin{array}{l}\text { Tharaka-Nithi, Nyeri, } \\
\text { Kirinyaga, }\end{array}$ & 3 & $8-10$ & Kajiado, Kisumu & 2 \\
\hline $1.1-3.0$ & $\begin{array}{l}\text { Lamu, Meru, Embu, } \\
\text { Machakos, } \\
\text { Nyandarua, } \\
\text { Murang'a, Kiambu, } \\
\text { Nakuru, Narok, } \\
\text { Bomet, Migori, } \\
\text { Nairobi City }\end{array}$ & 12 & $10.1-20$ & $\begin{array}{l}\text { West Pokot, Trans Nzoia, } \\
\text { Kisii, Nairobi City, Kericho, } \\
\text { Nandi }\end{array}$ & 6 \\
\hline $3.1-4.0$ & $\begin{array}{l}\text { Mombasa, Kwale, } \\
\text { Taita-Taveta, } \\
\text { Makueni, Nandi, } \\
\text { Kericho, Kakamega, } \\
\text { Bungoma, Siaya, } \\
\text { Kisumu, Homa Bay, } \\
\text { Kisii, Nyamira }\end{array}$ & 13 & $20.1-30$ & $\begin{array}{l}\text { Mombasa, Tharaka-Nthi, } \\
\text { Uasin Gishu, } \\
\text { Elgeyo/Marakwet, } \\
\text { Nyandarua, Kirinyaga, } \\
\text { Baringo, Homa Bay, Nyamira }\end{array}$ & 9 \\
\hline $4.1-5.0$ & $\begin{array}{l}\text { Kilifi, Trans-Nzoia, } \\
\text { Baringo, Vihiga }\end{array}$ & 4 & $30.1-40$ & $\begin{array}{l}\text { Kiambu, Nyeri, Migori, } \\
\text { Bungoma, Kakamega, } \\
\text { Nakuru, Laikipia, Samburu, } \\
\text { Embu, Kwale }\end{array}$ & 10 \\
\hline $5.1-6.0$ & $\begin{array}{l}\text { Kitui, } \\
\text { Elgeyo } \quad \text { Marakwet, } \\
\text { Kajiado }\end{array}$ & 4 & $40.1-50$ & $\begin{array}{l}\text { Lamu, Tana River, Murang’a, } \\
\text { Busia, Vihiga, Narok, } \\
\text { Machakos, Kitui, Meru, } \\
\text { Isiolo, Garissa, Taita/Taveta }\end{array}$ & 12 \\
\hline $6.1-7.0$ & $\begin{array}{l}\text { Wajir, } \\
\text { Laikipia }\end{array}$ & 3 & $50.1-60$ & $\begin{array}{l}\text { Siaya, Bomet, Turkana, } \\
\text { Makueni, Wajir, Kilifi }\end{array}$ & 6 \\
\hline $7.1-9.0$ & & & $60.1-70$ & Marsabit & 1 \\
\hline $9.1-10.0$ & $\begin{array}{l}\text { Tana River, West } \\
\text { Pokot, Busia }\end{array}$ & 3 & $70.1-80$ & Mandera & 1 \\
\hline $10.1-12.0$ & Garissa, Marsabit & 2 & & & \\
\hline $12.1-16.0$ & & & & & \\
\hline $16.1-17.0$ & Mandera, Samburu & 2 & & & \\
\hline $17.1-30.0$ & & & & & \\
\hline $30.1-31.0$ & Turkana & 1 & & & \\
\hline \multicolumn{2}{|c|}{ Total number of counties } & 47 & & & 47 \\
\hline
\end{tabular}

Source: Computed from KIHBS data 
Appendix 3: White cross-section test results

\begin{tabular}{|c|c|c|c|c|c|c|c|c|c|c|c|c|c|}
\hline 2006 & C & PSR & FPR & NONE & PRIMO & SECO & POSEC & NUT & MALE & FEMALE & RURAL & URBAN & AR(3) \\
\hline C & \begin{tabular}{|l|}
5924.82 \\
\end{tabular} & \begin{tabular}{|l|}
0.0876 \\
\end{tabular} & -0.3124 & \begin{tabular}{|l|}
-0.3072 \\
\end{tabular} & -0.0034 & 0.03897 & 1.0410 & \begin{tabular}{|l|}
0.0261 \\
\end{tabular} & \begin{tabular}{|l|}
-59.284 \\
\end{tabular} & -59.176 & 0.0462 & -0.005 & -0.0006 \\
\hline PSR & 0.0876 & \begin{tabular}{|l|}
0.0788 \\
\end{tabular} & -0.104 & \begin{tabular}{|l|}
-0.1441 \\
\end{tabular} & 0.0004 & 0.0308 & 0.1542 & -0.0659 & 0.0258 & -0.0352 & \begin{tabular}{|l|}
-0.0073 \\
\end{tabular} & -0.0034 & -0.0030 \\
\hline \begin{tabular}{|l|} 
FPR \\
\end{tabular} & -0.312 & \begin{tabular}{|l|}
-0.1041 \\
\end{tabular} & 0.7568 & 0.1956 & \begin{tabular}{|l|}
-0.0045 \\
\end{tabular} & 0.1819 & 0.1819 & 0.09924 & 0.7496 & -0.4119 & 0.1237 & 0.0228 & 0.0108 \\
\hline NONE & -0.3072 & \begin{tabular}{|l|}
-0.1441 \\
\end{tabular} & 0.0219 & \begin{tabular}{|l|}
-0.0118 \\
\end{tabular} & 0.2328 & \begin{tabular}{|l|}
-0.4032 \\
\end{tabular} & 0.1231 & \begin{tabular}{|c|}
-0.0123 \\
\end{tabular} & 0.4106 & -0.1121 & 0.0072 & 0.0169 & 0.0325 \\
\hline \begin{tabular}{|l|} 
PRIMO \\
\end{tabular} & -0.0034 & 0.0004 & -0.0045 & -0.0051 & 0.0002 & -0.0067 & -0.0138 & -0.0025 & 0.0051 & 0.0024 & \begin{tabular}{|l|}
-0.0013 \\
\end{tabular} & 7.2472 & 1.7349 \\
\hline \begin{tabular}{|l|} 
SECO \\
\end{tabular} & 0389 & 0.0309 & 0.1819 & 0.2550 & -0.0067 & 0.5196 & -0.2192 & \begin{tabular}{|l|}
0.1231 \\
\end{tabular} & -0.2249 & -0.1733 & 0.0298 & -0.0141 & -0.0003 \\
\hline POSEC & 1.0410 & 0.1542 & 0.7496 & $\mid-1.2446$ & $\mid-0.0138$ & -0.2192 & 35.1628 & 0.4106 & -0.9428 & -0.9002 & 0.3695 & -0.1102 & -0.1364 \\
\hline NUT & 0.0261 & $\mid-0.0659$ & 0.0993 & 0.2539 & -0.0025 & 0.1231 & 0.4106 & 0.2346 & -0.1121 & 0.0072 & 0.0169 & -0.0025 & -0.0003 \\
\hline \begin{tabular}{|l|} 
MALE \\
\end{tabular} & -59.2842 & 0.0258 & \begin{tabular}{|l|}
-0.4119 \\
\end{tabular} & -0.1203 & 0.0051 & -0.2249 & -0.9428 & -0.1121 & 0.9605 & 0.8575 & \begin{tabular}{|l|}
-0.1208 \\
\end{tabular} & -0.0181 & 0.0055 \\
\hline FEMALE & 59.1757 & $\mid-0.0352$ & -0.3529 & 0.1034 & 0.0024 & -0.1733 & -0.9002 & 0.0072 & 0.8575 & 0.9704 & -0.1071 & -0.0152 & -0.0025 \\
\hline RURAL & 0.0462 & \begin{tabular}{|l|}
-0.0073 \\
\end{tabular} & 0.1237 & \begin{tabular}{|l|}
-0.0305 \\
\end{tabular} & -0.0013 & 0.0298 & 0.3695 & \begin{tabular}{|l|}
0.0169 \\
\end{tabular} & -0.1208 & -0.1071 & 0.0544 & 0.0097 & -0.0039 \\
\hline URBAN & -0.0049 & -0.0034 & 0.0228 & -0.0051 & 7.2472 & .0141 & -0.1102 & -0.0025 & -0.0181 & -0.0152 & 0.0097 & 0.0059 & 0.0003 \\
\hline \begin{tabular}{|l|}
$\mathbf{A R}(3)$ \\
\end{tabular} & -0.0006 & \begin{tabular}{|l|}
-0.0030 \\
\end{tabular} & 0.0108 & 0.0326 & 1.7349 & \begin{tabular}{|l|}
-0.0003 \\
\end{tabular} & -0.1364 & \begin{tabular}{|c|}
-0.0003 \\
\end{tabular} & 0.0055 & \begin{tabular}{|l|}
-0.0025 \\
\end{tabular} & \begin{tabular}{|l|}
-0.0039 \\
\end{tabular} & 0.0003 & 0.0063 \\
\hline 20 & C & PSR & FPR & NONE & \begin{tabular}{|l|} 
PRIMO \\
\end{tabular} & SECO & POSEC & NUT & MALE & FEMALE & RURAL & URBAN & AR(3) \\
\hline C & 41.9891 & -2.2609 & -18.321 & \begin{tabular}{|l|}
1256.59 \\
\end{tabular} & -1519.78 & -1519.78 & -749.571 & -104.69 & -95.3259 & -43.7241 & -12.138 & -11.443 & -0.0006 \\
\hline \begin{tabular}{|l|} 
PSR \\
\end{tabular} & 41.9891 & 2.3199 & -0.3660 & 4.5560 & -12.4396 & 14.7848 & -18.4089 & -0.0421 & -20.3959 & 10.9171 & \begin{tabular}{|l|}
-0.0636 \\
\end{tabular} & -0.0455 & 0.0022 \\
\hline \begin{tabular}{|l|} 
FPR \\
\end{tabular} & -2.2609 & -0.3660 & 0.4638 & -2.2524 & 8.6937 & -10.5449 & 6.3812 & 0.0394 & 0.0104 & 0.0414 & 0.0015 & 0.0029 & 0.0006 \\
\hline \begin{tabular}{|l|} 
NONE \\
\end{tabular} & -104.693 & 4.5560 & \begin{tabular}{|l|}
-2.2524 \\
\end{tabular} & 274.779 & -696.199 & 827.624 & -1184.13 & 0.4831 & -87.4532 & 69.4998 & 0.1676 & 0.1999 & 0.0384 \\
\hline \begin{tabular}{|l|} 
PRIMO \\
\end{tabular} & 1256.585 & -12.44 & 8.6937 & \begin{tabular}{|l|}
-696.199 \\
\end{tabular} & 4299.773 & -5113.79 & -323.169 & -6.2076 & 896.179 & -758.481 & \begin{tabular}{|l|}
-2.5788 \\
\end{tabular} & -2.3323 & 0.0325 \\
\hline SECO & -1519.778 & 14.7848 & -10.545 & 827.624 & -5113.79 & 6082.401 & 385.608 & 7.3836 & -1084.21 & 918.415 & 3.1207 & 2.8298 & -0.0524 \\
\hline POSEC & -749.57 & -18.409 & 6.3812 & -1184.13 & -323.169 & 385.608 & 9463.69 & 4.3886 & -453.93 & 416.335 & 1.8918 & \begin{tabular}{|l|}
1.3067 \\
\end{tabular} & -0.2979 \\
\hline \begin{tabular}{|l|} 
NUT \\
\end{tabular} & -18.3211 & \begin{tabular}{|l|}
-0.0421 \\
\end{tabular} & 0.0394 & 0.4831 & -6.2076 & 0.0372 & 4.3886 & 0.2414 & 0.1229 & -0.2588 & 0.0409 & 0.0347 & -0.0039 \\
\hline MALE & -95.3259 & -20.40 & 0.0104 & -87.453 & 896.179 & -1084.21 & -453.927 & 0.1229 & 4785.517 & -4057.587 & 0.1955 & -0.3850 & 0.7921 \\
\hline FEMALE & -43.7241 & 10.9171 & 0.0414 & 69.4998 & -758.481 & 918.4148 & 416.335 & -0.2588 & -4057.59 & 3461.5047 & 0.0146 & \begin{tabular}{|l|}
0.4521 \\
\end{tabular} & -0.6872 \\
\hline RURAL & -12.1384 & -0.0636 & 0.0015 & 0.1676 & -2.5788 & 3.1207 & 1.8918 & 0.0409 & 0.1955 & 0.0146 & 0.0255 & 0.0238 & 5.8444 \\
\hline URBAN & -11.4428 & -0.0455 & 0.0029 & 0.1999 & -2.3323 & 2.8298 & 1.3067 & 0.0347 & -0.3850 & 0.4521 & 0.0238 & 0.0243 & 0.0003 \\
\hline \multirow[t]{2}{*}{$\overline{A R(3)}$} & -0.0006 & 0.0022 & 0.0006 & \begin{tabular}{|l|}
-0.0039 \\
\end{tabular} & 0.0384 & 0.0325 & -0.0524 & -0.2979 & 0.7921 & -0.6872 & 5.8444 & 0.0003 & 0.0063 \\
\hline & \multicolumn{13}{|c|}{ ations: 47} \\
\hline
\end{tabular}


Appendix 4: Multicollinearity

\begin{tabular}{|c|c|c|c|c|c|c|c|c|c|c|c|c|}
\hline 2006 & CTR & PSR & FPR & NONE & PRIMO & SECO & POSEC & NUT & MALE & FEMALE & RURAL & URBAN \\
\hline CTR & 1 & \begin{tabular}{|l|l|l|}
-0.1496 \\
\end{tabular} & -0.3152 & 0.0205 & -0.1209 & 0.3142 & 0.6925 & \begin{tabular}{|l|l|}
0.0034 \\
\end{tabular} & 0.0947 & -0.0948 & -0.4421 & 0.8636 \\
\hline PSR & -0.1496 & 1 & 0.5751 & 0.2344 & -0.0563 & -0.6199 & -0.3806 & 0.5075 & -0.3434 & 0.3433 & 0.0028 & -0.2439 \\
\hline FPR & -0.3152 & 0.5751 & 1 & 0.2273 & -0.0926 & -0.6841 & -0.4083 & 0.3805 & -0.1479 & 0.1476 & -0.0192 & -0.3707 \\
\hline NONE & 0.0205 & 0.2344 & 0.2273 & 1 & 0.0604 & \begin{tabular}{|l|}
-0.3979 \\
\end{tabular} & -0.0924 & 0.0872 & 0.1239 & -0.1239 & 0.2321 & -0.1783 \\
\hline PRIMO & \begin{tabular}{|l|}
-0.1209 \\
\end{tabular} & \begin{tabular}{|l|}
-0.0563 \\
\end{tabular} & -0.0926 & 0.0604 & 1 & 0.1532 & 0.0556 & \begin{tabular}{|l|}
-0.0548 \\
\end{tabular} & -0.0515 & 0515 & 0.0724 & -0.0152 \\
\hline SECO & 0.3142 & -0.6199 & -0.6841 & -0.3979 & 0.1532 & 1 & 0.5372 & -0.4092 & 0.3222 & -0.3221 & -0.2880 & 0.5573 \\
\hline POSEC & 0.6925 & -0.3806 & -0.4083 & -0.0924 & 0.0556 & 0.5372 & 1 & -0.0290 & 0.1687 & -0.1688 & -0.4577 & 0.7062 \\
\hline NUT & 0.0034 & 0.5075 & 0.3805 & 0.0872 & -0.0548 & -0.4092 & -0.0290 & 1 & -0.1357 & 0.13555 & -0.0627 & -0.1259 \\
\hline MALE & 0.0947 & -0.3434 & -0.1479 & 0.1239 & -0.0515 & 0.3222 & 0.1687 & -0.1357 & 1 & -0.9999 & -0.1513 & 0.2409 \\
\hline FEMALE & -0.0948 & 0.3433 & 0.1476 & -0.1239 & 0.0515 & -0.3221 & -0.1688 & 0.1356 & -0.9999 & 1 & 0.1515 & -0.2409 \\
\hline RURAL & -0.4421 & 0.0028 & -0.0192 & 0.2321 & 0.0724 & -0.2880 & -0.4577 & -0.0627 & -0.1514 & 0.1515 & 1 & -0.6127 \\
\hline URBAN & 0.8636 & -0.2439 & -0.3707 & -0.1783 & -0.0152 & 0.5573 & 0.7062 & \begin{tabular}{|l}
-0.1259 \\
\end{tabular} & 0.2409 & -0.2409 & -0.6127 & 1 \\
\hline 2010 & CTR & PSR & FPR & NONE & PRIMO & SECO & POSEC & NUT & MALE & FEMALE & RURAL & URBAN \\
\hline CTR & 1 & 0.2029 & 0.2636 & -0.1661 & -0.1633 & -0.1623 & -0.1662 & 0.0008 & 0.1825 & 0.1834 & 0.2504 & -0.2848 \\
\hline PSR & 0.2029 & 1 & 0.9342 & -0.4543 & -0.4534 & -0.4532 & -0.4542 & 0.6783 & 0.9899 & 0.9899 & 0.2313 & -0.3709 \\
\hline FPR & 0.2636 & 0.9342 & 1 & -0.4222 & -0.4171 & -0.4153 & -0.4222 & 0.5675 & 0.9202 & 0.9199 & 0.2423 & -0.3736 \\
\hline NONE & -0.1661 & -0.4543 & -0.4222 & 1 & 0.9994 & 0.9988 & 0.9999 & -0.3084 & -0.4510 & -0.4518 & -0.5421 & 0.8029 \\
\hline PRIMO & -0.1633 & -0.4534 & -0.4171 & 0.9994 & 1 & 0.9999 & 0.9994 & -0.3057 & -0.4506 & -0.4515 & -0.5410 & 0.7999 \\
\hline SECO & -0.1623 & -0.4532 & -0.4153 & 0.9988 & 0.9999 & 1 & 0.9988 & -0.3047 & -0.4506 & -0.4515 & -0.5404 & 0.7985 \\
\hline POSEC & -0.1662 & -0.4542 & -0.4222 & 0.9999 & 0.9994 & 0.9988 & 1 & -0.3084 & -0.4509 & -0.4517 & -0.5422 & 0.8031 \\
\hline NUT & 0.0008 & 0.6783 & 0.5675 & -0.3084 & -0.3057 & -0.3047 & -0.3084 & 1 & 0.6861 & 0.6875 & -0.0952 & -0.1252 \\
\hline MALE & 0.1825 & \begin{tabular}{|l|}
0.9899 \\
\end{tabular} & 0.9202 & -0.4510 & -0.4506 & -0.4506 & -0.4509 & 0.6861 & 1 & 0.9999 & 0.1921 & -0.3454 \\
\hline FEMALE & 0.1834 & 0.9899 & 0.9199 & -0.4518 & -0.4515 & -0.4515 & -0.4517 & 0.6875 & 0.9999 & 1 & 0.1919 & -0.3453 \\
\hline RURAL & 0.2504 & 0.2313 & 0.2423 & -0.5421 & -0.5410 & -0.5404 & -0.5422 & -0.0952 & 0.1921 & 0.1919 & 1 & -0.9067 \\
\hline URBAN & \begin{tabular}{|l|}
-0.2848 \\
\end{tabular} & -0.3709 & -0.3736 & 0.8029 & 0.7999 & 0.7985 & 0.8031 & -0.1252 & \begin{tabular}{|l|}
-0.3454 \\
\end{tabular} & -0.3453 & -0.9067 & 1 \\
\hline
\end{tabular}

